\title{
A New Environmental Friendly Clay Catalyst for One-pot Coiodination and Epoxidation of Alkenes
}

\author{
Karen S.M. Corrêa, ${ }^{a}$ Rafael B. Bernini, ${ }^{b}$ Marcio C.S. de Mattos, ${ }^{*, b}$ Mônica R.M.P. de Aguiar ${ }^{*, a}$ and \\ Alcides W.S. Guarino ${ }^{c}$ \\ ${ }^{a}$ Instituto de Química, Universidade do Estado do Rio de Janeiro, \\ 20590-900 Rio de Janeiro-RJ, Brazil \\ ${ }^{b}$ Instituto de Química, Universidade Federal do Rio de Janeiro, CP 68545 , \\ 21945-970 Rio de Janeiro-RJ, Brazil \\ ${ }^{c}$ Escola de Ciências Biológicas, Universidade Federal do Estado do Rio de Janeiro, \\ 22290-240 Rio de Janeiro-RJ, Brazil
}

\begin{abstract}
A argila comercial brasileira Bentonit Brasgel ${ }^{\circledR}$ foi caracterizada por análises química e textural, DRX e RMN no estado sólido de ${ }^{27} \mathrm{Al}$ and ${ }^{29} \mathrm{Si}$, que indicaram a presença de quartzo- $\alpha$ e esmectita como argilo-minerais. Essa argila se mostrou um catalisador eficiente para a conversão de alquenos nos respectivos epóxidos através da reação com iodo/água seguida de adição de $\mathrm{KOH}$ em hexano in situ (80-91\%). Resultados similares foram obtidos usando-se Bentonit Brasgel $^{\mathrm{TM}}$ intercalada com $\mathrm{Ag}(\mathrm{I})$.
\end{abstract}

The commercial Brazilian clay Bentonit Brasgel ${ }^{\mathrm{TM}}$ was characterized by chemical and textural analyses, XRD, and ${ }^{27} \mathrm{Al}$ and ${ }^{29} \mathrm{Si} \mathrm{MAS}-\mathrm{NMR}$, that indicated the presence of $\alpha$-quartz and smectite as clay-minerals. This natural clay proved to be an efficient catalyst for the conversion of alkenes into epoxides by the reaction with iodine/water followed by in situ addition of $\mathrm{KOH}$ in hexane (80-91\% yield). Similar results were obtained with Bentonit Brasgel ${ }^{\mathrm{TM}}$ intercalated with $\mathrm{Ag}(\mathrm{I})$.

Keywords: epoxide, coiodination, iodohydrin, clay, alkenes

\section{Introduction}

Nowadays, the search for cleaner process is one of the major challenges in modern chemical industries. ${ }^{1}$ Moreover, the high versatility, low-cost and gain in yield/ selectivity turn clays very attractive catalysts in the green chemistry point of view as they are reusable and present minimal environmental impact. ${ }^{2}$ Within this context, the use of clays and clay-minerals in synthetic organic chemistry has increased enormously in the last years. ${ }^{3}$

Epoxides are useful compounds in synthetic organic chemistry $^{3}$ and the interest for these valuable compounds has increased with the discovery of some biological activities related to the oxirane ring. ${ }^{5}$ There are several efficient methodologies for the preparation of epoxides, for example: the oxidation of alkenes with peracids and the cyclization of halohydrins with bases are the most

*e-mail:monica@pesquisador.cnpq.br; mmattos@iq.ufrj.br employed. ${ }^{4}$ Peracids and analogues have been used to prepare epoxides; even though, these reagents must be carefully manipulated, due to their tendency to explosion. ${ }^{6}$ The epoxidation of alkenes with molecular $\mathrm{O}_{2}$ or $\mathrm{H}_{2} \mathrm{O}_{2}$ seems to be very attractive, but it is expensive because it needs a metal-based catalytic system ${ }^{7}$ or zeolites ${ }^{8}$ and frequently suffers from formation of undesirable oxygenated by-products. Metal-free epoxidation of alkenes with $\mathrm{H}_{2} \mathrm{O}_{2}$ occurs in the presence of some auxiliaries (nitriles, carbodiimides, etc) which convert hydrogen peroxide to a more active oxidant. ${ }^{9}$ On the other hand, halohydrins are widely used in epoxide synthesis in both laboratorial and industrial scale. ${ }^{10}$ The cohalogenation ${ }^{11}$ with water (halogenation of alkenes in aqueous solutions) is an effective way to prepare these intermediates. ${ }^{12}$ Although this methodology is effective, the handling and manipulation of toxic and corrosive halogens is problematic (especially in large-scale), then the search for alternative sources of electrophilic halogen is of great interest. $^{13}$ 
Recently, we have developed a green and consistent route to iodohydrins by coiodination of alkenes with water (reaction of alkenes with $\mathrm{I}_{2} / \mathrm{H}_{2} \mathrm{O}$ ) catalyzed by some clayminerals. ${ }^{14}$ Our results showed that natural Brazilian clays F-117 (a smectite) and F-101 (an interstratified structure with smectite, kaolinite and mica as clay-minerals) proved to be superior to commercial $\mathrm{KSF}^{\mathrm{TM}}$ and $\mathrm{K}-10^{\mathrm{TM}}$ clays. ${ }^{15}$ Furthermore, the Brazilian clays are also superior to other methodologies traditionally applied to perform coiodination of alkenes; such as, excess iodine or catalysis by heavy metal salts. ${ }^{16}$

Herein, we communicate our results on the characterization and utilization of Bentonit Brasgel ${ }^{\mathrm{TM}}$, a commercial Brazilian clay, as an effective catalyst for the preparation of epoxides from alkenes.

\section{Results and Discussion}

Figure 1 shows the XRD patterns of commercial Brazilian clay, Bentonit Brasgel ${ }^{\mathrm{TM}}$, an activated sodic clay. It presents a strong reflection at $13.598 \AA\left(2 \theta=6.5^{\circ}\right)$ which indicates the presence of smectite. ${ }^{15}$ In addition, this sample shows a peak at $3.38 \AA\left(2 \theta=26.7^{\circ}\right)$ corresponding to $\alpha$-quartz. ${ }^{17}$

Table 1 shows the results of the Bentonit Brasgel ${ }^{\mathrm{TM}}$ chemical analysis. As observed, this material presents iron contents around $10 \%$ and the $\mathrm{Si} / \mathrm{Al}$ ratio of $c a .4: 1$.

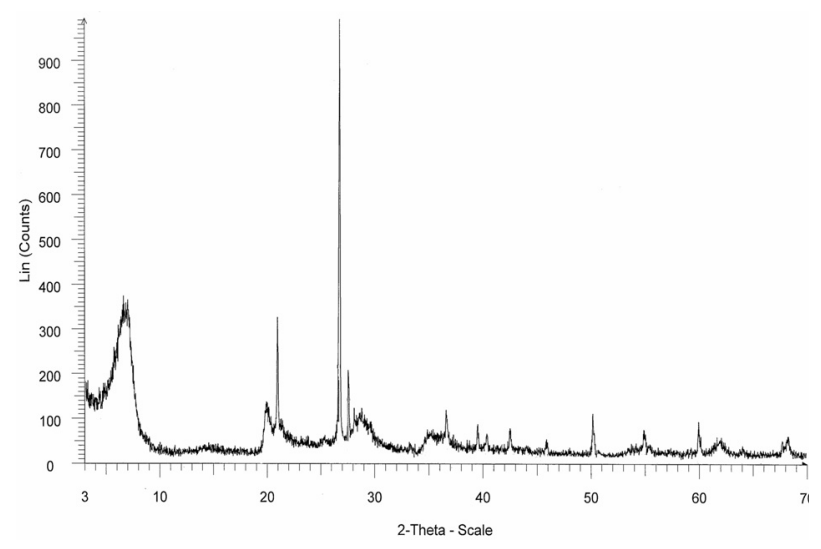

Figure 1. XRD patterns of Bentonit Brasgel ${ }^{\mathrm{TM}}$ clay.

Table 1. Chemical analysis of Bentonit clay

\begin{tabular}{lc}
\hline Element & $\%$ \\
\hline $\mathrm{SiO}_{2}$ & 66.00 \\
$\mathrm{Al}_{2} \mathrm{O}_{3}$ & 16.40 \\
$\mathrm{Fe}_{2} \mathrm{O}_{3}$ & 9.26 \\
$\mathrm{MgO}_{2}$ & 2.72 \\
$\mathrm{NaO}$ & 2.34 \\
$\mathrm{TiO}_{2}$ & 0.90 \\
$\mathrm{CaO}_{2}$ & 1.44 \\
Others & 0.94 \\
\hline
\end{tabular}

Textural analysis of commercial Bentonit Brasge ${ }^{\mathrm{TM}}$ clay showed a micropore volume of $0.015 \mathrm{~cm}^{3} \mathrm{~g}^{-1}$. This clay exhibits analogous hysteresis, characteristic of mesoporous solids. The surface area $\left(92.99 \mathrm{~m}^{2} \mathrm{~g}^{-1}\right)$ is quite close to the others Brazilian clays, as pore diameter is $41.2 \AA$ and specific external area is $58.7 \mathrm{~m}^{2} \mathrm{~g}^{-1} \cdot{ }^{15}$

The ${ }^{27} \mathrm{Al}$ MAS-NMR spectra of Bentonit Brasgel ${ }^{\mathrm{TM}}$ (Figure S1 in Supplementary Information) shows a peak at $55.72 \mathrm{ppm}$ due to tetrahedral $\mathrm{Al}$ ions (4.4\% relative area) and another one at $4.42 \mathrm{ppm}$ which can be attributed to octahedral $\mathrm{Al}$ sites ( $95.6 \%$ relative area).

The analysis of ${ }^{29} \mathrm{Si}$ MAS-NMR spectra of the Bentonit Brasgel $^{\mathrm{TM}}$ clay (Figure S2 in Supplementary Information) presented two broad signal: the region of $\mathrm{Q}^{3}(\mathrm{nAl})$ between -70 and $-93 \mathrm{ppm}$ was attributed the presence of Si from the clay framework, and the peak in the range from -106 to $-130 \mathrm{ppm}$ indicated to $\alpha$-quartz and amorphous silica, $\mathrm{Q}^{4}(0 \mathrm{Al}) \cdot{ }^{15}$

The activity of this commercial clay compared to other catalysts was determined in the coiodination of styrene with $\mathrm{MeOH}$ to produce 2-iodo-1-phenyl methyl ether (Table 2). The reaction was carried out for $6 \mathrm{~h}$ at room temperature by stirring with the catalyst, $5 \mathrm{mmol}$ of styrene and $10 \mathrm{mmol}$ of $\mathrm{I}_{2}$ in $\mathrm{MeOH}$. The reaction was highly regiosselective and only one product was detected by the analytical techniques employed. All the catalysts used led to the same $\beta$-iodoether and in the absence of any catalyst the yield was poor. The reactions catalyzed by clays, by $\mathrm{Cu}(\mathrm{OAc})_{2}$ or excess $\mathrm{I}_{2}^{18}$ gave better yield and the best results were obtained using clays as catalysts. The natural Brazilian clays F-117 and F-101 (early used as catalyst for this kind of reaction) $)^{14-16,19}$ as well as Bentonit Brasgel ${ }^{\mathrm{TM}}$ clay produced the $\beta$-iodoether in similar yields and superior to Montmorillonite $\mathrm{K}-10^{\mathrm{TM}}$ clay. As it is well known that metal salts can catalyze the coiodination reactions, ${ }^{20}$ the

Table 2. Yields of 2-iodo-1-phenyl methyl ether

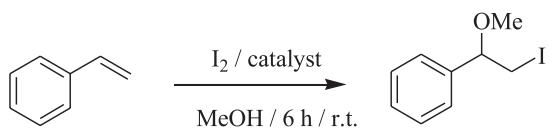

\begin{tabular}{lc}
\hline Catalyst & ${\text { Yield } /(\%)^{\mathrm{a}}}^{\mathrm{a}}$ \\
\hline- & 52 \\
$\mathrm{Cu}(\mathrm{OAc})_{2}$ & 70 \\
$\mathrm{I}_{2}$ & 78 \\
$\mathrm{~K}-10^{\mathrm{TM}}$ & 80 \\
$\mathrm{~F}-101$ & 87 \\
$\mathrm{~F}-117$ & 89 \\
Bentonit Brasgel $^{\mathrm{TM}}$ & 90 \\
Bentonit-Ag $_{\text {Bentonit-Cu }}$ & 91 \\
\end{tabular}

aYield of pure product, based on styrene. 
commercial Bentonit Brasgel ${ }^{\mathrm{TM}}$ clay intercalate with $\mathrm{Ag}(\mathrm{I})$ and with $\mathrm{Cu}$ (II) were prepared (Bentonit-Ag and Bentonit$\mathrm{Cu})$. However, these catalysts provided similar activity to the natural clay.

A kinetic study comparing F-117, Bentonit Brasgel ${ }^{\mathrm{TM}}$, Bentonit- $\mathrm{Cu}$ clays and the uncatalyzed reaction was performed through the coiodination of styrene with $\mathrm{MeOH}$. The conversion of the substrate to 2-iodo-1-phenyl methyl ether was monitored by HRGC using pentadecane as internal standard. Figure 2 demonstrates that the uncatalyzed reaction is very slow, and although all the clays have similar activity in $6 \mathrm{~h}$, intercalated Bentonit showed a higher catalytic effect in a small reaction time.

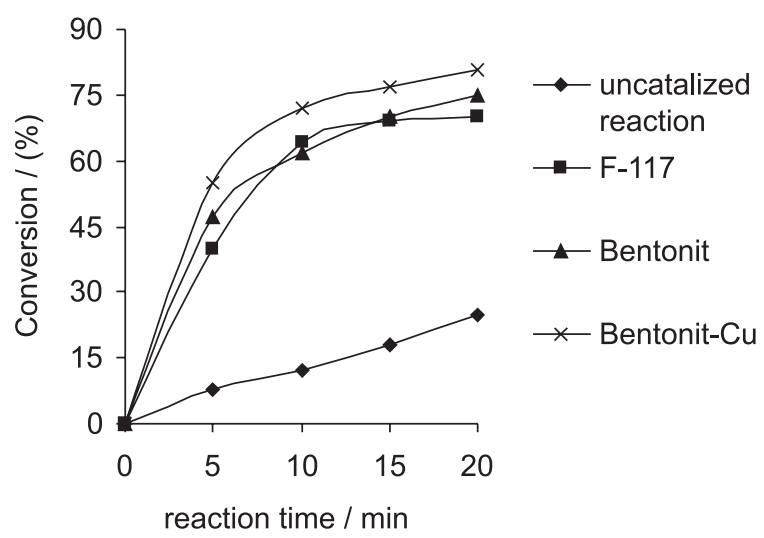

Figure 2. Conversion of styrene into 2-iodo-1-phenyl methyl ether catalyzed by clays as a function of the reaction time.

Metals are essential in coiodination reactions to decompose the $\pi$-complex formed among alkene and iodine to the bridged iodonium ion (Scheme 1). ${ }^{16}$ Hence, the better catalytic effect of Bentonit- $\mathrm{Cu}$ clay showed in Figure 2 could be explained in terms of its higher concentration of metal in the structure.

Based on the above results, the coiodination of diverse alkenes with water was performed using $\mathrm{I}_{2}$ ( 2 mol equiv.) and Bentonit Brasgel ${ }^{\mathrm{TM}}(0.2 \mathrm{~g})$ clay in aqueous dioxane at room temperature. After 4 hours, $\mathrm{KOH}$ was added in a biphasic system ${ }^{13}$ (hexane/water) to produce the pure epoxides in excellent yields after $30 \mathrm{~min}$. The HRGC of these crude reactions indicated the respective epoxide as the unique product. Neither unreacted alkene nor the intermediated iodohydrin were detected. As it is well-known that $\operatorname{Ag}(\mathrm{I})$ salts can assist solvolysis of alkyl halide, ${ }^{21}$ the coiodination of alkenes mediated by Bentonit-Ag clay was tested. Using this procedure, the iodohydrins were efficiently obtained, but only traces of epoxides were formed. However, using Bentonit-Ag clay as catalyst for the coiodination reaction, followed by one-pot addition of the $\mathrm{KOH} /$ biphasic system, produced smoothly the corresponding epoxides in higher yields. Table 3 summarizes all the results.

\section{Conclusions}

The preparation of epoxides by reaction of alkenes with iodine in the presence of the Commercial Brazilian clay followed by in situ cyclization with $\mathrm{KOH}$ in a biphasic system is efficiently achieved. This simple methodology is an alternative route for the epoxidation of acid-sensitive alkenes or the epoxidation of alkenes yielding acidsensitive epoxides. Furthermore, our methodology is safe and very attractive considering the environmental issues that require the substitution of toxic reagents by friendlier solid catalysts and the advantages of heterogeneous catalysis in terms of easy work up procedures. ${ }^{2}$

\section{Experimental}

\section{General}

The commercial Brazilian Bentonit Brasgel ${ }^{\mathrm{TM}}$ clay was kindly donated by Bentonit União do Nordeste Co. All chemicals are commercially available and were used without further purification. At the end of reactions the solvent was evaporated on a rotatory evaporator and then concentrated under reduced pressure $(267 \mathrm{~Pa})$ and $50{ }^{\circ} \mathrm{C}$ (bath).

\section{Characterization of Bentonit Brasgel ${ }^{T M}$ clay}

Chemical analyses of the clay samples were made using an Inductive Couple Plasma emission



Scheme 1. Metal-catalyzed coiodination of alkene. 
Table 3. Yield of epoxides

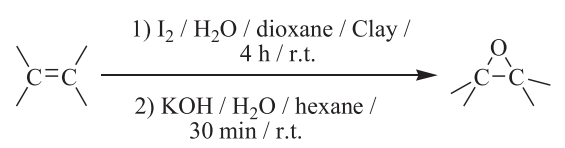

\begin{tabular}{|c|c|c|c|}
\hline \multirow[t]{6}{*}{ Alkene } & \multirow[t]{2}{*}{ Epoxide } & \multicolumn{2}{|c|}{ Yield / $(\%)^{\mathrm{a}}$} \\
\hline & & Bentonit Brasgel $^{\mathrm{TM}}$ & Bentonit-Ag \\
\hline & & 91 & 99 \\
\hline & & 80 & 83 \\
\hline & & 82 & 91 \\
\hline & & 90 & 92 \\
\hline
\end{tabular}

aield of pure product, based on the alkene.

spectroscopy (ICP-AES) on a Perkin-Elmer plasma. Surface area and pore size distribution of the samples were determined by adsorption-desorption of nitrogen at $77 \mathrm{~K}$ using Micromeritics A.S.A.P. 2000. Surface area was calculated using BET isotherm method. X-ray diffraction studies were performed with an automated SIEMENS type-F diffractometer in step scanning mode $\theta-2 \theta$. The high-voltage was supplied by a high stability Philips PW1830/25 generator. A graphite monochromator was used to select copper $\mathrm{K} \alpha$-doublet ( $\lambda \cong 1.54 \AA$ ). The scanning was performed in fixedtime mode in the interval $2^{\circ} \leq 2 \theta \leq 45^{\circ}$ with a step increment of $0.05^{\circ}$. Solid state nuclear magnetic resonance spectra were obtained on a Bruker DRX300 spectrometer (7.05 Tesla), operating at $59.6 \mathrm{MHz}\left({ }^{29} \mathrm{Si}\right)$ and $78.2 \mathrm{MHz}\left({ }^{27} \mathrm{Al}\right)$. A $4 \mathrm{~mm}$ MAS probe and spinning rates of $5 \mathrm{kHz}$ for ${ }^{29} \mathrm{Si}$ and $12 \mathrm{kHz}$ for ${ }^{27} \mathrm{Al}$ were employed. Samples of kaolinite (-91.5 ppm) and $\mathrm{AlCl}_{3} \cdot 6 \mathrm{H}_{2} \mathrm{O}(0.0 \mathrm{ppm})$ were used as external references.

\section{Characterization of reaction products}

${ }^{1} \mathrm{H}$ NMR and ${ }^{13} \mathrm{C}$ NMR spectra were acquired on a Bruker AC-200 (200 MHz and $50 \mathrm{MHz}$, respectively) spectrometer for $\mathrm{CDCl}_{3}$ solutions with TMS as internal standard. HRGC analysis were performed on a HP-5890II gas chromatograph with FID by using a $30 \mathrm{~m}$ (length), $0.25 \mathrm{~mm}$ (ID) and $25 \mu \mathrm{m}$ (phase thickness) RTX-5 silica capillary column and He (flow rate $50 \mathrm{~cm} \mathrm{~s}^{-1}$ ) as carrier gas (split 1:20). Mass spectra were obtained on a HewlettPackard HP5896-A HRGC-MS using electron impact ionization $(70 \mathrm{eV})$.
Typical procedure for the preparation of intercalated Bentonit clays

Commercial Bentonit Brasgel ${ }^{\mathrm{TM}}$ clay was intercalated with $\mathrm{Cu}(\mathrm{II})$ or $\mathrm{Ag}(\mathrm{I})$ by treating it with solution of the corresponding metal salt $\left(\mathrm{CuSO}_{4}\right.$ or $\left.\mathrm{AgNO}_{3}, 10 \% \mathrm{p} / \mathrm{v}\right)$. This mixture was kept at $60{ }^{\circ} \mathrm{C}$ under stirring for $24 \mathrm{~h}$. After the exchange, the intercalated clays were filtered, washed several times with deionized water, and dried at $110{ }^{\circ} \mathrm{C}$ for $12 \mathrm{~h}$.

Preparation of 2-Iodo-1-phenyl methyl ether Typical procedure for coiodination of styrene with methanol mediated by clays

To a stirred suspension of styrene $(5 \mathrm{mmol})$ and the clay $(0.2 \mathrm{~g})$ in methanol $\left(20 \mathrm{~cm}^{3}\right)$, was added iodine $(10$ $\mathrm{mmol})$ in small portions at room temperature. After $6 \mathrm{~h}$, the clay was filtered off, $\mathrm{Et}_{2} \mathrm{O}\left(10 \mathrm{~cm}^{3}\right)$ was added and the organic layer was washed with a saturated solution of $\mathrm{Na}_{2} \mathrm{~S}_{2} \mathrm{O}_{3}\left(3 \times 5 \mathrm{~cm}^{3}\right)$. The organic extract was dried (anhydrous $\mathrm{Na}_{2} \mathrm{SO}_{4}$ ) and filtered through a small column of $\mathrm{SiO}_{2}$. The solvent was evaporated to give 2-iodo-1phenyl methyl ether pure as a colorless oil. The identity of the product was determined by comparison of its analytical data with the previously reported. ${ }^{22}$

${ }^{1} \mathrm{H}$ NMR: $\delta 3.20(\mathrm{~s}, 3 \mathrm{H}), 3.32(\mathrm{dd}, J 4.4$ and $9.0 \mathrm{~Hz}$, 2H), 4.45-4.30 (dd, J 4.4 and $8.8 \mathrm{~Hz}, 1 \mathrm{H}), 7.35(\mathrm{~m}, 5 \mathrm{H})$ ppm. ${ }^{13} \mathrm{C} \mathrm{NMR:} \delta 10.2\left(\mathrm{CH}_{2}\right), 57.2\left(\mathrm{CH}_{3}\right), 83.4(\mathrm{CH}), 126.0$ (CH), $128.2(\mathrm{CH}), 128.9(\mathrm{CH}), 140.1$ (C). MS: m/z 77, 91, 104, $121(100 \%), 135,262\left(\mathrm{M}^{+}, 2 \%\right)$. 


\section{Kinetic study}

The coiodination of styrene with methanol catalyzed by clays was performed as described above. The conversion of the substrate into 2-iodo-1-phenyl methyl ether at different reaction times was determined by HRGC using pentadecane as internal standard.

Typical procedure for the preparation of epoxides

To a stirred suspension of styrene $(5 \mathrm{mmol})$ and the clay $(0.2 \mathrm{~g})$ in dioxane $\left(20 \mathrm{~cm}^{3}\right)$, was added iodine (10 mmol) in small portions at room temperature for $4 \mathrm{~h}$. Then $\mathrm{KOH}$ (34 mmol) was added to the two-phase solution in the 1:1 ratio of hexane/dioxane. After $30 \mathrm{~min}$, $\mathrm{CH}_{2} \mathrm{Cl}_{2}\left(15 \mathrm{~cm}^{3}\right)$ was added and the organic layer separated, washed with a saturated solution of $\mathrm{Na}_{2} \mathrm{~S}_{2} \mathrm{O}_{3}$ $\left(3 \times 5 \mathrm{~cm}^{3}\right)$, dried (anhydrous $\left.\mathrm{Na}_{2} \mathrm{SO}_{4}\right)$ and filtered through a small column of $\mathrm{SiO}_{2}$. The solvent was evaporated to give the pure epoxide as a colorless (or light orange) oil. The identity of the product was determined by comparison of its analytical data with the previously reported. ${ }^{11}$

\section{Cyclohexene oxide}

${ }^{1} \mathrm{H}$ NMR: $\delta$ 1.37-1.16 (m, 4H), 1.87-1.74 (m, 4H), 3.05 (s, 2H), ppm. ${ }^{13} \mathrm{C}$ NMR: $\delta 19.4\left(\mathrm{CH}_{2}\right), 24.2\left(\mathrm{CH}_{2}\right)$, $55.1(\mathrm{CH})$ ppm. MS: $m / z$ 69, $83(100 \%), 97,98\left(\mathrm{M}^{+}\right.$, $3 \%)$.

\section{Styrene oxide}

${ }^{1} \mathrm{H}$ NMR: $\delta 2.79(\mathrm{dd}, J 5.5 \mathrm{~Hz}$ and $2.6 \mathrm{~Hz}, 1 \mathrm{H}), 3.13$ (dd, $J 5.5 \mathrm{~Hz}$ and $4.0 \mathrm{~Hz}, 1 \mathrm{H}$ ), 3.86 (dd $J 2.6 \mathrm{~Hz}$ and 4.0 $\mathrm{Hz}, 1 \mathrm{H}), 7.34(\mathrm{~m}, 5 \mathrm{H}) \mathrm{ppm} .{ }^{13} \mathrm{C} \mathrm{NMR}: \delta 51.3\left(\mathrm{CH}_{2}\right)$, $52.5(\mathrm{CH}), 125.6(\mathrm{CH}), 128.3(\mathrm{CH}), 128.9(\mathrm{CH}), 137.7$ (C) ppm. MS: m/z 54, 89, 90, $91(100 \%), 119,120\left(\mathrm{M}^{+}\right.$, $30 \%)$.

\section{$\alpha$-Methylstyrene oxide}

${ }^{1} \mathrm{H}$ NMR: $\delta 1.69$ (s, 3H), 2.92 (d, 1H), $3.00(\mathrm{~d}, 1 \mathrm{H})$, 7.30 (m, 5H), ppm. ${ }^{13} \mathrm{C}$ NMR: $\delta 21.9\left(\mathrm{CH}_{3}\right), 56.9\left(\mathrm{CH}_{2}\right)$, $57.1(\mathrm{CH}), 124.9\left(\mathrm{CH}_{2}\right), 127.6\left(\mathrm{CH}_{2}\right), 128.5\left(\mathrm{CH}_{2}\right), 141.3$

(C) ppm. MS: $m / z$ 78, 103, 105, 106, 133 (100\%), 134 $\left(\mathrm{M}^{+}, 20 \%\right)$

\section{1-Octene oxide}

${ }^{1} \mathrm{H}$ NMR: 0.88 (t, 3H), 1.20-1.55 (m, 10H), 2.45 (dd, $J 8.2$ and $3.9 \mathrm{~Hz}, 1 \mathrm{H}), 2.75(\mathrm{dd}, J 8.2$ and $1.1 \mathrm{~Hz}, 1 \mathrm{H})$, $2.98(\mathrm{~m}, 1 \mathrm{H}) \mathrm{ppm} .{ }^{13} \mathrm{C}$ NMR: $14.0\left(\mathrm{CH}_{3}\right), 22.6\left(\mathrm{CH}_{2}\right), 26.1$ $\left(\mathrm{CH}_{2}\right), 29.2\left(\mathrm{CH}_{2}\right), 31.8\left(\mathrm{CH}_{2}\right), 32.5\left(\mathrm{CH}_{2}\right), 47.0\left(\mathrm{CH}_{2}\right)$, $52.4(\mathrm{CH}) \mathrm{ppm}$.

\section{Acknowledgments}

We thank CNPq and FAPERJ for financial support. M.C.S.M. and M.R.M.P.A. thank CNPq for fellowships. R.B.B. and K.S.M.C. thank PIBIC/UFRJ, PIBIC/UERJ, and FAPERJ for fellowships. We are also grateful to Bentonit Brazilian Corporation for natural Brazilian Bentonit Brasgel ${ }^{\mathrm{TM}}$ clay donation.

\section{Supplementary Information}

${ }^{27} \mathrm{Al}$ MAS-NMR (Figure S1) and ${ }^{29} \mathrm{Si}$ MAS-NMR spectrum of Bentonit Brasgel ${ }^{\mathrm{TM}}$ clay (Figure S2) are available free of charge at http://jbcs.sbq.org.br, as PDF file.

\section{References}

1. Sheldon, R. A.; Downing, R. S.; Appl. Catal., A 1999, 189, 163.

2. Anastas, P.T.; Warner, J.C.; Green Chemistry: Theory and Practice, Oxford University Press: Oxford, 2000; Lenardão, E. J.; Freitag, R. A.; Dabdoub, M. J.; Batista, A. C. F.; Silveira, C. C.; Quim. Nova 2003, 26, 123.

3. Badathala, V.; Synlett 2004, 388; Varma, R. S.; Tetrahedron 2002, 58, 1235; Vaccari, A.; Appl. Clay Sci. 1999, 14, 161.

4. Smith, J. G.; Synthesis 1984, 629; Rao, A. S.; Paknikar, S. K.; Kirtane, J. G.; Tetrahedron 1983, 39, 2323.

5. Marco-Contelles, J.; Molina, M. T.; Anjum, S.; Chem. Rev. 2004, 104, 2857.

6. Bretherick, L.; Hazards in the Chemical Laboratory; $4^{\text {th }}$ ed; Royal Society of Chemistry: London, 1986; pp. 446-447.

7. Recent examples: Liu, S.-Y.; Nocera, D. G.; Tetrahedron Lett. 2006, 47, 1923; Kureshy, R. I.; Singh, S.; Khan, N. H.; Abdi, S. H. R.; Ahmed, I.; Bhatt, A.; Jasra, R. V.; Catal. Lett. 2006, 107, 127; Rebelo, L. H.; Gonçalves, A. R.; Pereira, M. M.; Simões, M. M. Q.; Neves, M. G. P. M. S.; Cavaleiro, J. A. S.; J. Mol. Catal. A: Chem. 2006, 256, 321.

8. Corma, A.; J. Catal. 2003, 216, 298.

9. Grigoropoulou, G.; Clark, J. H.; Elings, J. A.; Green Chem. 2003, 5,1 ;

10. Weissermel, K.; Industrial Organic Chemistry, $3^{\text {rd }}$ ed; WileyVCH: Wienheim, 1997; pp. 266, 267.

11. Sanseverino, A. M.; da Silva, F. M.; Jones Jr., J.; de Mattos, M. C. S. Quim. Nova 2001, 24, 637; Rodriguez, J.; Dulcère, J.-P.; Synthesis 1993, 1177.

12. Sanseverino, A. M.; de Mattos, M. C. S.; Synth. Commun. 1998, 28,559

13. Wengert, M.; Sanseverino, A. M.; de Mattos, M. C. S.; J. Braz. Chem. Soc. 2002, 13, 700.

14. Villegas, R. A. S.; de Aguiar, M. R. M. P.; de Mattos, M. C. S., Guarino, A. W. S.; Barbosa, L. M.; Assumpção, L. C. F. N.; J. Braz. Chem. Soc. 2004, 15, 150. 
15. Villegas, R. A. S.; Santo Jr., J. L. E.; de Mattos, M. C. S., de Aguiar, M. R. M. P.; Guarino, A. W. S.; J. Braz. Chem. Soc. 2005, 16, 565.

16. Villegas, R. A. S.; Santo Jr., J. L. E.; de Mattos, M. C. S., de Aguiar, M. R. M. P.; Guarino, A. W. S. Catal. Commun. 2007, $8,97$.

17. Guarino, A. W. S.; San Gil, R. A. S.; Polivanov, H.; Menezes, S. M. C.; J. Braz. Chem. Soc. 1997, 8, 581.

18. Sanseverino, A. M.; de Mattos, M. C. S.; Synthesis 1998, 1584.

19. Villegas, R. A. S.; Santo Jr., J. L. E.; Sanseverino, A. M.; de Mattos, M. C. S., de Aguiar, M. R. M. P.; Guarino, A. W. S.; Synth. Commun. 2005, 35, 1627.
20. de Mattos, M. C. S.; Sanseverino, A. M.; J. Chem. Res. 2004, 638; de Mattos, M. C. S.; Sanseverino, A. M.; J. Chem. Res. (S) 1994, 440.

21. Schauble, J. H.; Trauffer, E. A.; Deshpande, P. P.; Evans, R. D.; Synthesis 2005, 1333; Vona, J. A.; Steigman, J.; J. Am. Chem. Soc. 1959, 81, 1095.

22. Yusubov, M. S.; Yusubova, R. Y.; Filimonov, V. D.; Ki-Whan, C.; Russ. J. Org. Chem. 2002, 38, 902.

Received: June 18, 2007 Web Release Date: December 7, 2007 


\section{A New Environmentally Friendly Clay Catalyst for One-pot Coiodination and Epoxidation of Alkenes}

Karen S.M. Corrêa, ${ }^{a}$ Rafael B. Bernini, ${ }^{b}$ Marcio C.S. de Mattos, ${ }_{c}^{*, b}$ Mônica R.M.P. de Aguiar ${ }^{*, a}$ and Alcides W.S. Guarino ${ }^{c}$

${ }^{a}$ Instituto de Química, Universidade do Estado do Rio de Janeiro, 20590-900 Rio de Janeiro-RJ, Brazil

${ }^{b}$ Instituto de Química, Universidade Federal do Rio de Janeiro, CP 68545 , 21945-970 Rio de Janeiro-RJ, Brazil

${ }^{c}$ Escola de Ciências Biológicas, Universidade Federal do Estado do Rio de Janeiro, 22290-240 Rio de Janeiro-RJ, Brazil

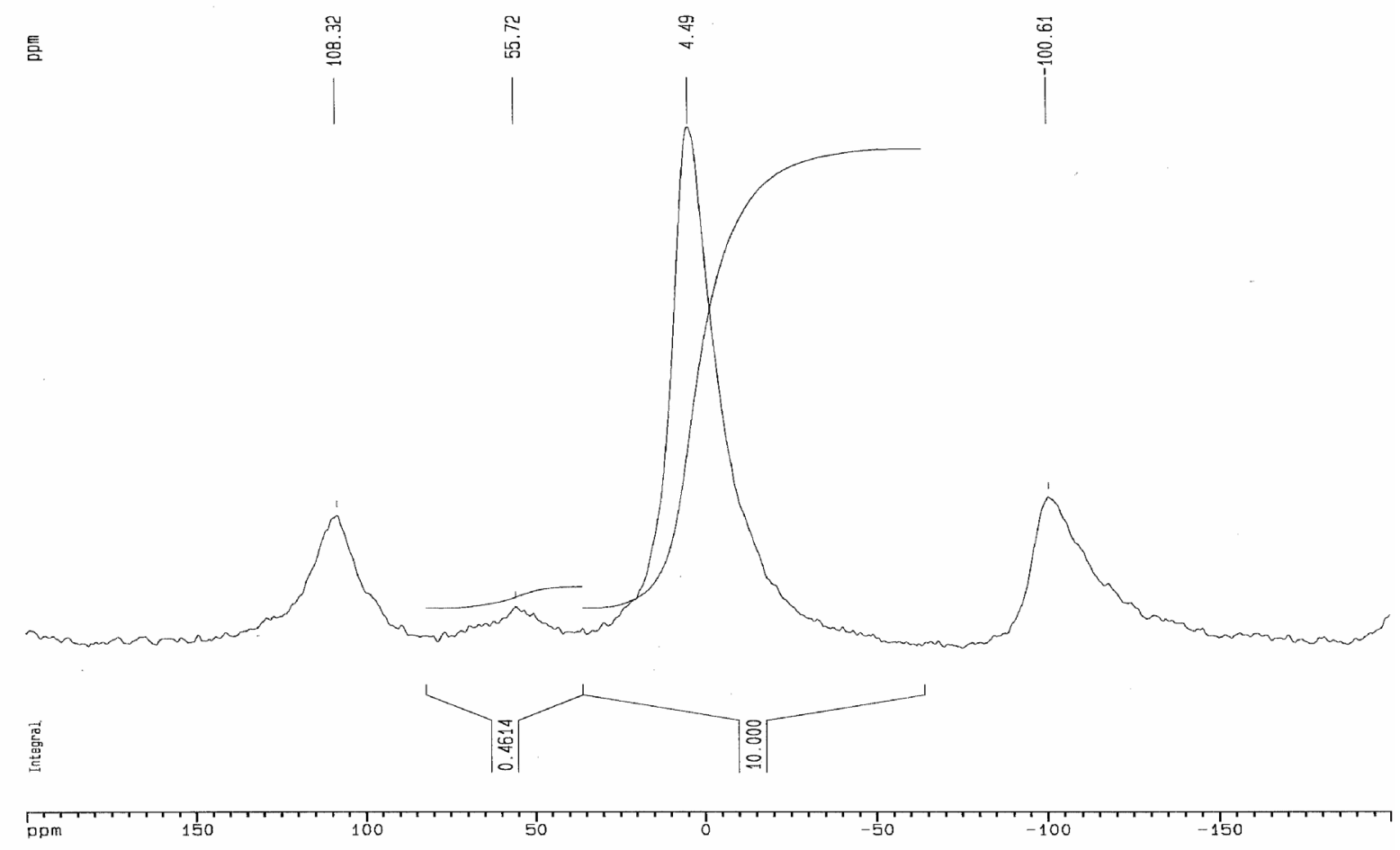

Figure S1. ${ }^{27} \mathrm{Al}$ MAS-NMR spectra of Bentonit Brasgel ${ }^{\mathrm{TM}}$ clay.

*e-mail: monica@pesquisador.com.br; mmattos@iq.ufrj.br 


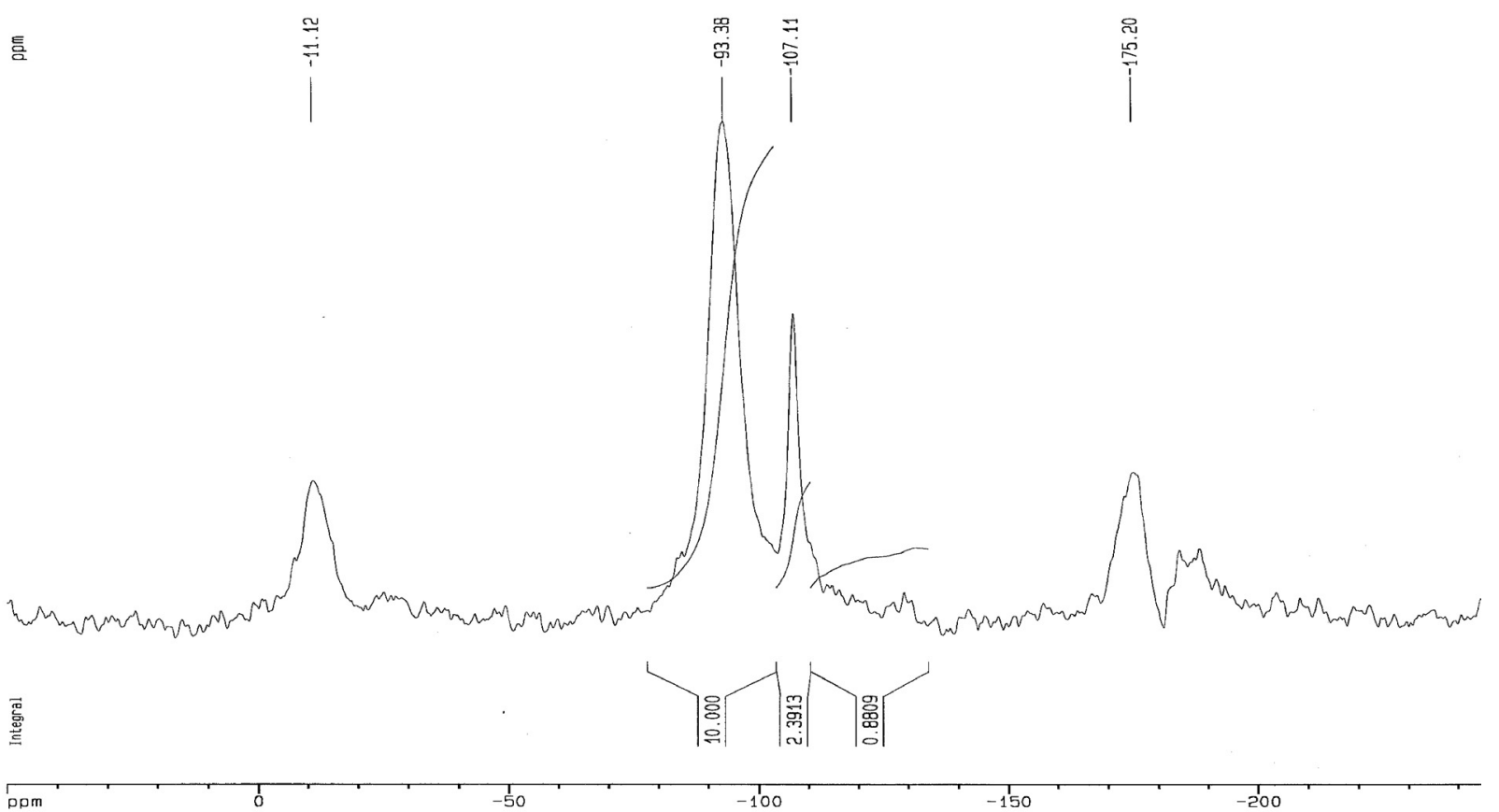

Figure S2. ${ }^{29}$ Si MAS-NMR spectra of Bentonit Brasgel ${ }^{\mathrm{TM}}$ clay. 